\title{
PERBANDINGAN TINGKAT KETERGANTUNGAN ANTARA PENGGUNA ROKOK KONVENSIONAL DAN PENGGUNA ROKOK ELEKTRONIK
}

\author{
Taufiq Abdullah*, Ungky Agus Setyawan ${ }^{* *}$, Audri Shabrina Fadhila***
}

\begin{abstract}
Abstrak
Rokok elektronik sering dianggap kurang adiktif dibandingkan rokok konvensional (tembakau). Penelitian ini bertujuan untuk mengetahui perbedaan tingkat ketergantungan pada pengguna rokok konvensional dan pengguna rokok elektronik pada usia remaja sampai dewasa muda. Penelitian menggunakan metode observasional analitik dengan pendekatan cross sectional melalui survei menggunakan kuesioner online terhadap 48 responden yang terdiri dari 22 pengguna rokok elektronik, 13 pengguna rokok konvensional dan 12 pengguna keduanya pada usia remaja sampai dewasa muda. Evaluasi tingkat ketergantungan menggunakan kuesioner Fagerström test for nicotine dependence (FTND). Pengukuran motivasi alasan merokok menggunakan kuesioner Horn's smoker's self test. Analisis data menggunakan analsis statistik nonparametrik Mann-Whitney test dan Kruskal Wallis. Hasil penelitian ini menemukan bahwa perokok elektronik mempunyai tingkat ketergantungan nikotin yang lebih tinggi (ratarata 2,18) dibandingkan perokok konvensional (rata-rata 1,15; $p<0,05$ ). Hasil Mann-Whitney test didapatkan nilai signifikansi $p<0,05$ untuk tingkat ketergantungan nikotin berdasarkan motivasi alasan merokok adalah ketagihan (craving), sedangkan didapatkan nilai signifikansi $p>0,05$ untuk tingkat ketergantungan nikotin berdasarkan motivasi alasan merokok pada kategori stimulasi, kesenangan, crutch, kebiasaan, stres, dan sosial. Kesimpulan penelitian ini, terdapat perbedaan signifikan tingkat ketergantungan antara pengguna rokok konvensional dan rokok elektronik dengan tingkat ketergantungan lebih tinggi pada pengguna rokok elektronik.
\end{abstract}

Kata kunci: ketergantungan, motivasi perokok, pengguna rokok elektronik, pengguna rokok konvensional

\section{COMPARISON OF ADDICTION LEVELS BETWEEN CONVENTIONAL CIGARETTE USERS AND ELECTRONIC CIGARETTE USERS}

\begin{abstract}
E-cigarettes are often considered less addictive than traditional cigarettes. This study aimed to determine the differences in the addiction level between conventional cigarette users with electronic cigarette users from adolescents to young adults. An observational analytic study with a cross-sectional approach was conducted with a survey of 48 respondents consisting of 22 e-cigarette users, 13 conventional cigarette users, and 12 users both in teens to young adults using an online questionnaire. Evaluation of the level of addiction using the Fagerström test for nicotine dependence questionnaire (FTND). The motivation for smoking was measured by using Horn's smoker's self test questionnaire. Data analysis used non-parametric statistical analysis of the Mann-Whitney test and Kruskal Wallis. The results of this study indicated that E-cigarette smokers had a higher rate of nicotine addiction (mean 2.18) than conventional smokers (mean 1.15; $p<0.05$ ). Mann-Whitney test showed a $p<0.05$ significance value based on the motivation for smoking reasons in the craving category, meanwhile showed a $p>0.05$ significance value based on the motivation for smoking reasons in the stimulation, pleasure, crutch, habit, stress, and social. The conclusion is there was a significant difference in the level of nicotine addiction between conventional smokers and electronic smokers with higher addiction levels in e-cigarette users.
\end{abstract}

Keywords: addiction, conventional cigarette users, electronic cigarette users, smokers motivation

\footnotetext{
${ }^{*}$ Departemen Emergensi Medisin, Fakultas Kedokteran, Universitas Brawijaya

** Departemen IImu Kedokteran Respirasi dan Pulmonologi, Fakultas Kedokteran, Universitas Brawijaya

${ }^{* * *}$ Program Studi Pendidikan Dokter, Fakultas Kedokteran, Universitas Brawijaya

E-mail: audreydhila@gmail.com
} 


\section{Pendahuluan}

Merokok merupakan salah satu ancaman kesehatan masyarakat terbesar di dunia. Menurut WHO, angka kematian yang disebabkan oleh rokok mencapai lebih dari 8 juta orang per tahun di dunia. ${ }^{1}$ Menurut WHO prevalensi merokok pada laki-laki dan perempuan usia 15 tahun ke atas di dunia pada tahun 2016 adalah 19,9\%. ${ }^{1}$ Sementara di Indonesia, menurut RISKESDAS 2018 pada kelompok yang sama pada tahun 2018 prevalensi mencapai $33,8 \%$ dan mengalami kenaikan dari tahun 2015 yang prevalensinya adalah $12,7 \%$. $^{2}$

Alasan awal seorang pemuda merokok hanya untuk coba-coba, sarana sosial, dan kesenangan dapat berpotensi menjadi ketergantungan nikotin. 3,4 Hal ini dikarenakan efek reward dari zat yang menyebabkan ketergantungan pada rokok, yaitu nikotin. ${ }^{5}$ Nikotin akan menstimulasi reseptor nicotinic cholinergic di otak yang merangsang berbagai neurotransmitter. Salah satu neurotransmitter yang dirangsang adalah dopamin. Nikotin akan merangsang rilis dopamin di area mesolimbic, corpus striatum, dan korteks frontal. Adanya paparan nikotin secara kronis lambat laun menyebabkan reseptor nicotinic cholinergic akan terdesensitisasi sehingga akan muncul rasa craving dan withdrawal apabila nikotin tidak mencapai batas ambang. Jika pengguna memutuskan untuk berhenti menggunakan rokok secara tiba-tiba maka akan terjadi gejala putus obat (withdrawal symptoms) yang antara lain iritabilitas, depressive, mood, kegelisahan dan ansietas. ${ }^{6}$

Mekanisme nicotine replacement therapy (NRT) adalah mengalihkan konsumsi nikotin kepada alat yang bukan rokok tanpa tambahan bahan kimia berbahaya yang terkandung di dalam rokok. Penggunaan NRT dapat membantu pengguna rokok untuk memuaskan keinginan merokok dan mengurangi penggunaan rokok secara perlahan sampai dengan keadaan abstinens dengan mengurangi gejala putus obat. ${ }^{7}$ Alat NRT yang direkomendasikan adalah gum, transdermal patch, nasal spray, inhaler dan sublingual tablets/lozenges. ${ }^{8}$ Selain itu, alat yang saat ini banyak digunakan untuk NRT di kalangan masyarakat adalah rokok elektronik atau oleh WHO disebut Electronic Nicotine Delivery System (ENDS). ${ }^{9}$
Rokok elektronik merupakan suatu perangkat elektronik bertenaga baterai yang melepaskan nikotin aerosol tanpa proses pembakaran tembakau untuk inhalasi. ${ }^{4}$

Pengguna rokok elektronik semakin lama semakin meningkat. Menurut RISKESDAS 2018, prevalensi pengguna rokok elektronik pada kelompok usia 10-18 tahun adalah 2,7\% dan untuk kelompok usia 15 tahun adalah $10,9 \% .{ }^{2}$ Angka ini mengalami peningkatan dari prevalensi yang didapatkan oleh SIRKESNAS 2016 yaitu secara berurutan sebesar 2,0\% dan 2,1\%.9 Peningkatan dari penggunaan rokok elektronik terjadi akibat promosi dari pihak penjual yang menggunakan klaim kesehatan yang tidak sesuai dengan bukti ilmiah Klaim kesehatan yang diutarakan antara lain sebagai alat berhenti merokok, menghasilkan asap yang aman, tidak mengandung zat adiktif dan sebagai gaya hidup yang sehat.10

Rokok elektronik tidak direkomendasikan sebagai alat bantu untuk berhenti merokok. Hal ini karena hasil penelitian mengenai keefektifan rokok elektronik sebagai alat berhenti merokok masih mendapatkan hasil yang berbeda-beda. ${ }^{1}$ Walaupun rokok elektronik dipandang sebagai sarana untuk berhenti merokok, tidak menutup kemungkinan bahwa rokok elektronik dapat menjadi "gateway drug" atau jembatan menuju ketergantungan tembakau dan nikotin pada remaja. $^{3}$

Penelitian mengenai ketergantungan nikotin pada pengguna rokok elektronik dibandingkan dengan rokok konvensional masih mendapatkan hasil yang beragam. Penelitian Jankowski et al., menggunakan Fragerstorm test for nicotine dependence (FTND) untuk mengetahui tingkat ketergantungan nikotin pada pengguna rokok konvensional dan pengguna rokok elektronik mendapatkan hasil skor FTND pengguna rokok elektronik (rata-rata $=3,5$ ) lebih besar daripada skor FTND pengguna rokok konvensional (rata-rata $=1,6) \cdot{ }^{11}$

Penelitian terdahulu belum membedakan motivasi seseorang untuk menggunakan rokok elektronik apakah sebagai sarana untuk berhenti merokok atau untuk kesenangan, craving, stimulasi, crutch, kebiasaan, faktor stres, atau faktor sosial seperti halnya alasan menggunakan rokok konvensional. ${ }^{12}$ 
Oleh karena itu, peneliti tertarik untuk mengetahui lebih dalam mengenai perbedaan tingkat ketergantungan pada pengguna rokok konvensional dengan pengguna rokok elektronik dengan memasukkan faktor psikososial yang menjadi motivasi orang untuk menggunakan rokok elektronik.

\section{Bahan dan Metode}

\section{Desain Penelitian}

Penelitian ini menggunakan metode observasional analitik melalui pendekatan cross sectional dengan analisis multivariat melalui pengambilan data pengguna rokok konvensional, pengguna rokok elektronik ataupun keduanya di seluruh Indonesia dengan menggunakan kuesioner online menggunakan Google Form. Penelitian ini dilaksanakan pada September 2020Desember 2020. Peneloitian ini telah dinyatakan laik etik oleh Komisi Etik Penelitian Kesehatan, Fakultas Kedokteran Universitas Brawijaya dengan nomor surat 119/EC/KEPK-S1-PD/06/2020.

\section{Variabel Penelitian}

Variabel bebas pada penelitian ini adalah perokok konvensional dan perokok elektronik serta variabel psikososial yang terkait dalam ketergantungan merokok yang terdiri dari faktor-faktor stimulasi, kesenangan, craving, crutch, kebiasaan dan stres. Variabel terikat pada penelitian ini adalah tingkat ketergantungan nikotin yang didapatkan dari hasil kuesioner Fragerstroom test for nicotine dependence (FTND) yang diisi oleh responden.

\section{Tempat dan Waktu Penelitian}

Penelitian dilakukan secara daring dengan menggunakan kuesioner online berupa google form sehingga lokasi penelitian tidak terbatas dalam satu wilayah. Pemilihan lokasi penelitian mempertimbangkan keadaan pandemi karena COVID-19. Penelitian dilakukan pada bulan September 2020-Desember 2020.

\section{Prosedur Penelitian}

Prosedur pengambilan data dilakukan menggunakan kuesioner online berupa google form, kemudian disebarkan ke target responden yang diketahui merokok dan meminta responden tersebut untuk menyebarkan kuesioner online kepada temannya yang juga merokok (snowballing sampling).

\section{Analisis Data}

Data yang diperoleh dari subjek penelitian diolah dan dianalisis dengan menggunakan program Statistical Package for Social Sciences (SPSS) 20 dengan uji normalitas menggunakan KolmogorovSmirnov. Kemudian menggunakan analisis nonparametrik Mann-Whitney dan Kruskal Wallis untuk membandingkan ketiga kelompok yang diamati. Data yang dibandingkan adalah kategori dari Fragerstroom test dan kategori dari Horn's smoker's self test.

Hasil

Pada penelitian ini didapatkan 13 responden yang menggunakan rokok konvensional, ada sebanyak 11 orang dengan tingkat ketergantungan yang rendah, 1 orang dengan tingkat ketergantungan yang sedang, dan 1 orang dengan tingkat ketergantungan yang tinggi. Pengguna rokok elektronik sebanyak 22 orang, ada sebanyak 12 orang dengan tingkat ketergantungan yang rendah, 9 orang dengan tingkat ketergantungan yang sedang, dan 1 orang dengan tingkat ketergantungan yang tinggi. Sedangkan dari 13 orang yang menggunakan rokok konvensional dan elektronik, ada sebanyak 12 orang dengan tingkat ketergantungan yang rendah, 1 orang dengan tingkat ketergantungan yang sedang, dan tidak ada yang mempunyai tingkat ketergantungan yang tinggi (Tabel 1).

Kemudian, didapatkan bahwa pengguna rokok elektronik memiliki frekuensi penggunaan yang lebih banyak di atas 10 kali per hari dibandingkan dengan sebagian besar pengguna ganda yang menggunakan rokok elektronik di bawah 10 kali per hari. Namun demikian, diketahui bahwa rata-rata kadar nikotin yang tertera pada kemasan liquid rokok elektronik dan rokok konvensional yang digunakan oleh pengguna ganda lebih tinggi $(13,92 \mathrm{mg})$ dibandingkan kelompok responden yang hanya menggunakan rokok elektronik (10,97 mg) (Gambar 1 dan 2). 
Tabel 1. Tingkat ketergantungan berdasarkan jenis rokok yang digunakan

\begin{tabular}{lcccccccc}
\hline Tingkat ketergantungan & $\begin{array}{c}\text { Rokok } \\
\text { Konvensional }\end{array}$ & $\begin{array}{c}\text { Rokok } \\
\text { Elektronik }\end{array}$ & $\begin{array}{c}\text { Rokok } \\
\text { Konvensional } \\
\text { \& Elektronik }\end{array}$ & Total \\
\cline { 2 - 9 } & $\mathrm{f}$ & $\%$ & $\mathrm{f}$ & $\%$ & $\mathrm{f}$ & $\%$ & $\mathrm{f}$ & $\%$ \\
\hline Ketergantungan rendah & 11 & 22,9 & 12 & 25 & 12 & 25 & 35 & 72,9 \\
Ketergantungan sedang & 1 & 2,1 & 9 & 18,8 & 1 & 2,1 & 11 & 22,9 \\
Ketergantungan tinggi & 1 & 2,1 & 1 & 2,1 & 0 & 0 & 2 & 4,2 \\
Total & 13 & 27,1 & 22 & 45,8 & 13 & 27, & 48 & 100,0 \\
\hline
\end{tabular}

$\because \leq 5$ kali $\quad 6-10 \mathrm{kali}=11-15 \mathrm{kali}=\geq 16 \mathrm{kali}$

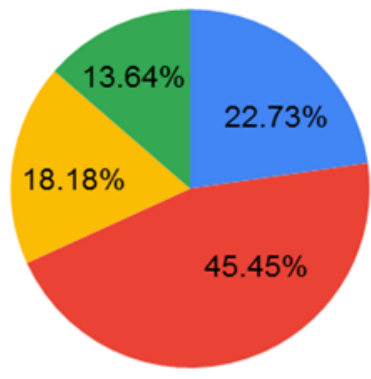

Pengguna rokok elektronik
$=5$ kali $\quad=6-10$ kali

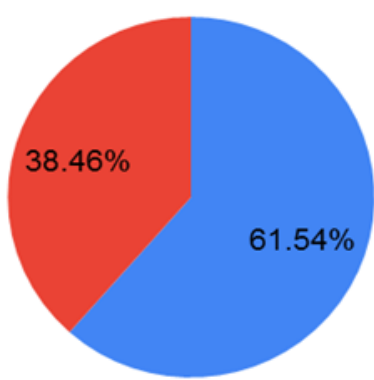

Pengguna rokok elektronik dan konvensional

Gambar 1. Frekuensi menggunakan rokok elektronik saja serta rokok elektronik dan konvensional per hari

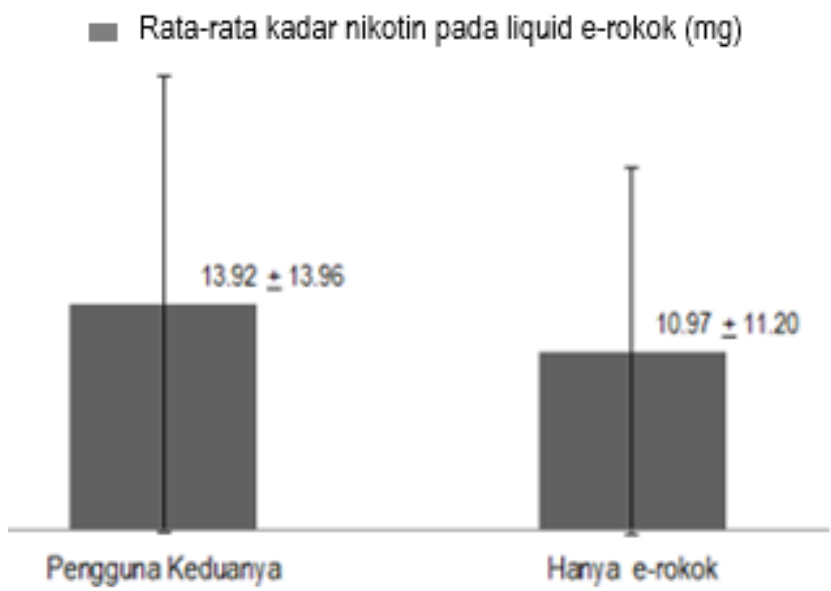

Gambar 2. Rata-rata kadar nikotin (mg) pada kemasan liquid rokok elektronik

Keterangan: Pengguna ganda adalah perokok yang menggunakan rokok elektronik dan rokok konvensional; e-rokok adalah hanya menggunakan rokok elektronik

Hasil pengujian normalitas data menggunakan kolmogorov-smirnov test diperoleh hasil penyebaran data yang tidak normal $(\mathrm{p}=$ 0,068; di atas 5\%, namun masih di bawah $10 \%$ ), sehingga pengujian perbandingan tingkat ketergantungan nikotin pada kelompok sampel menggunakan statistik nonparametrik. Uji statistik nonparametrik yang digunakan yaitu Mann Whitney U test dan Kruskal Wallis test (Tabel 2). 
Berdasarkan hasil uji Kruskal Wallis terdapat perbedaan tingkat ketergantungan nikotin pada perokok konvensional, perokok elektronik, dan keduanya $(p=0,021<0,05)$. Kemudian hasil uji Mann Whitney $U$ menunjukkan bahwa tingkat ketergantungan nikotin pada kelompok yang menggunakan rokok elektronik berbeda signifikan dengan tingkat ketergantungan nikotin pada kelompok yang menggunakan rokok konvensional $(p=$ $0,015<0,05)$, dan yang menggunakan keduanya $(p=0,045<0,05)$. Perbandingan tingkat ketergantungan nikotin pada kelompok rokok konvensional tidak berbeda signifikan (bermakna) dengan tingkat ketergantungan nikotin pada kelompok yang menggunakan rokok konvensional dan elektronik (pengguna ganda) ( $p=0,840>0,05)$ (Tabel 2).

Berdasarkan Horn's smokers self test diperoleh informasi bahwa dari 48 orang pengguna rokok yang menjadi responden dalam penelitian ini, sebanyak 20 orang $(41,7 \%)$ yang merokok dengan alasan stimulasi, 38 orang $(79,2 \%)$ merokok dengan alasan kesenangan, 9 orang $(18,8 \%)$ merokok dengan alasan craving, 24 orang $(50 \%)$ merokok dengan alasan sebagai crutch, 17 orang $(35,4 \%)$ merokok dengan alasan faktor kebiasaan, 33 orang $(68,8 \%)$ merokok dengan alasan stres, dan 15 orang $(31,3 \%)$ merokok dengan alasan faktor sosial (Tabel 3).

Hasil uji perbandingan menunjukkan bahwa tidak terdapat perbedaan yang signifikan untuk tingkat ketergantungan nikotin pada para pengguna rokok yang mempunyai motivasi merokok karena adanya stimulasi, kesenangan, crutch, kebiasaan, faktor stres, dan faktor sosial dengan tingkat ketergantungan nikotin, masing-masing diperoleh nilai $p$ sebesar $0,071,0,896,0,275,0,260$, 0,413 , dan $0,125(p>0,05)$. Sedangkan untuk motivasi alasan merokok karena craving terdapat perbedaan yang signifikan untuk tingkat ketergantungan nikotin $(p=0,002<$ 0,05) (Tabel 4).

Tabel 2. Hasil uji perbandingan tingkat ketergantungan pengguna rokok konvensional, rokok elektronik dan keduanya

\begin{tabular}{|c|c|c|c|c|c|c|c|c|}
\hline & \multicolumn{3}{|c|}{ Skor FTND } & \multirow{2}{*}{$\begin{array}{c}\begin{array}{l}\text { Uji Norma- } \\
\text { litas Data }\end{array} \\
p\end{array}$} & \multicolumn{3}{|c|}{$\begin{array}{l}\text { Uji Perbandingan } \\
\text { Berganda*) }\end{array}$} & \multirow{2}{*}{$\frac{\begin{array}{c}\text { Semua } \\
\left.\text { Kelompok }^{* *}\right)\end{array}}{\mathrm{p} 4}$} \\
\hline & Median & $\begin{array}{l}\text { Rata- } \\
\text { rata }\end{array}$ & SD & & $\mathrm{p} 1$ & p2 & p3 & \\
\hline $\begin{array}{l}\text { Pengguna } \\
\text { rokok elektronik } \\
\text { dan } \\
\text { konvensional }\end{array}$ & 1 & 0,92 & 1,19 & & & & & \\
\hline $\begin{array}{l}\text { Konvensional } \\
\text { Rokok } \\
\text { elektronik }\end{array}$ & 2 & 2,18 & 1,47 & 0,068 & $0,015^{*}$ & 0,045 & 0,840 & $0,021^{*}$ \\
\hline Konvensional & 1 & 1,15 & 1,52 & & & & & \\
\hline
\end{tabular}

Keterangan: $S D=$ Standard Deviasi, $p<0,05=$ ada perbedaan pada level signifikan $5 \%, p<0,10=$ ada perbedaan pada level signifikan 10\%, *) Hasil dari U Mann-Whitney test, *) Hasil dari Kruskal Wallis test, $\mathrm{p} 1$ = perbandingan e-rokok dan konvensional, $\mathrm{p} 2$ = perbandingan e-rokok dan pengguna ganda, $\mathrm{p3}$ = perbandingan konvensional dan pengguna ganda

Tabel 3. Distribusi frekuensi motivasi alasan merokok responden

\begin{tabular}{lcccc}
\hline \multirow{2}{*}{ Kategori Horn's Smoker Self Test } & \multicolumn{2}{c}{ Tidak } & \multicolumn{2}{c}{ Ya } \\
& Frekuensi & $\%$ & Frekuensi & $\%$ \\
\hline Stimulasi & 28 & $58,3 \%$ & 20 & $41,7 \%$ \\
Kesenangan & 10 & $20,8 \%$ & 38 & $79,2 \%$ \\
Craving & 39 & $81,3 \%$ & 9 & $18,8 \%$ \\
Crutch & 24 & $50,0 \%$ & 24 & $50,0 \%$ \\
Kebiasaan & 31 & $64,6 \%$ & 17 & $35,4 \%$ \\
Stres & 15 & $31,3 \%$ & 33 & $68,8 \%$ \\
Sosial & 33 & $68,8 \%$ & 15 & $31,3 \%$ \\
\hline
\end{tabular}


Tabel 4. Hasil uji perbandingan antara motivasi alasan merokok dengan tingkat ketergantungan nikotin

\begin{tabular}{|c|c|c|c|c|c|c|c|c|}
\hline \multirow{2}{*}{$\begin{array}{c}\text { Kategori } \\
\text { Horn's } \\
\text { Smoker Self } \\
\text { Test }\end{array}$} & & \multicolumn{2}{|c|}{$\begin{array}{c}\text { Ketergantungan } \\
\text { Rendah }\end{array}$} & \multicolumn{2}{|c|}{$\begin{array}{c}\text { Ketergantungan } \\
\text { Sedang }\end{array}$} & \multicolumn{2}{|c|}{$\begin{array}{c}\text { Ketergantungan } \\
\text { Tinggi } \\
\end{array}$} & \multirow{2}{*}{$p$} \\
\hline & & Frek & $\%$ & Frek & $\%$ & Frek & $\%$ & \\
\hline \multirow{2}{*}{ Stimulasi } & $\mathrm{Ya}$ & 12 & $34,3 \%$ & 6 & $54,5 \%$ & 2 & $100,0 \%$ & \multirow{2}{*}{0,071} \\
\hline & Tidak & 23 & $65,7 \%$ & 5 & $45,5 \%$ & 0 & $0,0 \%$ & \\
\hline \multirow{2}{*}{ Kesenangan } & Ya & 28 & $80,0 \%$ & 8 & $72,7 \%$ & 2 & $100,0 \%$ & \multirow{2}{*}{0,896} \\
\hline & Tidak & 7 & $20,0 \%$ & 3 & $27,3 \%$ & 0 & $0,0 \%$ & \\
\hline \multirow{2}{*}{ Craving } & Ya & 3 & $8,6 \%$ & 4 & $36,4 \%$ & 2 & $100,0 \%$ & \multirow{2}{*}{$0,002^{*}$} \\
\hline & Tidak & 32 & $91,4 \%$ & 7 & $63,6 \%$ & 0 & $0,0 \%$ & \\
\hline \multirow{2}{*}{ Crutch } & Ya & 16 & $45,7 \%$ & 6 & $54,5 \%$ & 2 & $100,0 \%$ & \multirow{2}{*}{0,275} \\
\hline & Tidak & 19 & $54,3 \%$ & 5 & $45,5 \%$ & 0 & $0,0 \%$ & \\
\hline \multirow{2}{*}{ Kebiasaan } & Ya & 11 & $31,4 \%$ & 4 & $36,4 \%$ & 2 & $100,0 \%$ & \multirow{2}{*}{0,260} \\
\hline & Tidak & 24 & $68,6 \%$ & 7 & $63,6 \%$ & 0 & $0,0 \%$ & \\
\hline \multirow{2}{*}{ Stres } & Ya & 23 & $65,7 \%$ & 8 & $72,7 \%$ & 2 & $100,0 \%$ & \multirow{2}{*}{0,413} \\
\hline & Tidak & 12 & $34,3 \%$ & 3 & $27,3 \%$ & 0 & $0,0 \%$ & \\
\hline \multirow{2}{*}{ Sosial } & Ya & 9 & $25,7 \%$ & 4 & $36,4 \%$ & 2 & $100,0 \%$ & \multirow{2}{*}{0,125} \\
\hline & Tidak & 26 & $74,3 \%$ & 7 & $63,6 \%$ & 0 & $0,0 \%$ & \\
\hline
\end{tabular}

Keterangan: ${ }^{*} p<0,05=$ ada perbedaan pada level signifikan $5 \%$

\section{Pembahasan}

Pada penelitian ini didapatkan bahwa tingkat ketergantungan nikotin yang diukur dengan FTND pada pengguna rokok elektronik lebih tinggi (rata-rata 2,18) dibandingkan dengan perokok konvensional (rata-rata 1,$15 ; p<0,05$ ). Tingkat ketergantungan nikotin pada pengguna rokok elektronik juga lebih tinggi dibandingkan dengan pengguna ganda (rata-rata 0,$92 ; p<$ 0,05 ). Tingkat ketergantungan nikotin yang tinggi yang diketahui dari skor rata-rata FTND pada pengguna rokok elektronik dibandingkan dengan perokok konvensional (tembakau) pada responden remaja-dewasa muda (16-30 tahun) menunjukkan bahwa kelompok tersebut berisiko tinggi mengalami kecanduan.

Sejalan dengan temuan Jankowski et al., yang juga menemukan tingkat kecanduan yang lebih tinggi di antara pengguna rokok eletronik dibandingkan dengan perokok konvensional, namun dengan tingkat kecanduan pengguna rokok elektronik yang lebih rendah. ${ }^{11}$ Tingkat kecanduan pengguna rokok elektronik pada penelitian ini mempunyai rata-rata skor FTND $=2,18$, sedangkan rata-rata skor FTND pengguna rokok elektronik pada penelitian Jankowski et al., adalah 3,50. Perbedaan tersebut dapat disebabkan teknologi atau regulasi yang berbeda di tiap negara. Selain itu, pasar rokok elektronik dengan cepat berubah dengan model dan generasi rokok elektronik yang lebih baru. ${ }^{11}$

Pada penelitian ini juga ditemukan bahwa pengguna ganda menggunakan rokok elektronik dengan kadar nikotin yang lebih tinggi (rata-rata $13.91 \mathrm{mg}$ ) dibandingkan dengan pengguna yang hanya menggunakan rokok elektronik (rata-rata $10.97 \mathrm{mg}$ ). Namun, pengguna rokok elektronik mempunyai durasi penggunaan rokok elektronik yang lebih lama dibandingkan dengan pengguna ganda. Hal ini menunjukkan bahwa pengguna rokok elektronik menggunakan rokok elektronik yang mengandung nikotin dan memerlukan puff lebih banyak untuk mencapai kadar nikotin yang sama dengan pengguna rokok konvensional. Oleh karena itu, para pengguna rokok elektronik tetap berpotensi terhadap ketergantungan karena tabung dengan tegangan tinggi pada rokok elektronik dapat mengalirkan nikotin dalam jumlah besar ke dalam tubuh. Bahkan tubuh lebih rentan menyerap banyak nikotin saat vaping. ${ }^{11}$ 
Rokok elektronik terutama yang memiliki baterai atau akumulator berkapasitas tinggi, ditandai dengan produksi aerosol dalam volume yang lebih besar dan pengiriman nikotin dengan dosis yang jauh lebih tinggi dibandingkan dengan rokok elektronik model lama (generasi pertama atau kedua). ${ }^{12}$ Berbeda dengan hasil penelitian González et al., bahwa pengguna rokok elektronik memiliki nilai FTND yang lebih rendah (rata-rata = $4,38)$ dibandingkan perokok konvensional (rata-rata $=5,57 ; p=0,03$ ). ${ }^{13}$ Etter et al., menyimpulkan bahwa rokok elektronik kurang adiktif dibandingkan rokok konvensional. Namun demikian, potensi kecanduan pengguna rokok elektronik sebanding dengan kadar nikotin. ${ }^{14}$

Populasi penelitian ini adalah pengguna rokok elektronik dewasa muda berusia antara 16 sampai 30 tahun, dibandingkan dengan penelitian sebelumnya oleh González et al., Etter et al., dan Liu et al., yang menggunakan populasi semua kelompok usia remaja sampai dewasa. ${ }^{13-15}$

Pola merokok pada populasi yang lebih muda dapat berbeda dengan perokok yang lebih tua, karena perokok yang lebih tua cenderung merokok lebih banyak per hari dibandingkan dengan remaja, sehingga berpeluang mempunyai skor FTND yang lebih tinggi. ${ }^{16}$ Namun, remaja dan dewasa muda (di bawah 25 tahun) juga memiliki risiko terbesar kecanduan nikotin. ${ }^{11}$ Faktor-faktor ini dapat berkontribusi pada skor FTND yang lebih tinggi yang ditemukan di antara pengguna rokok elektronik dibandingkan di antara pengguna rokok konvensional.

Rokok elektronik dipromosikan sebagai alternatif yang lebih aman dibandingkan rokok konvensional. ${ }^{17,18}$ Pengguna rokok elektronik menganggap rokok elektronik kurang berbahaya dibandingkan orang yang menggunakan rokok konvensional atau pengguna ganda. Studi yang dilakukan di Selandia Baru dan Jerman menunjukkan bahwa ada kepercayaan publik terkait rokok elektronik dapat membantu dalam berhenti merokok. ${ }^{13-15}$ Namun, temuan penelitian ini menunjukkan bahwa penggunaan rokok elektronik memiliki potensi untuk menimbulkan ketergantungan dan risiko ketergantungan mungkin lebih tinggi dibandingkan risiko dari rokok tembakau yang dihisap, terutama di antara orang dewasa muda. Hal ini dapat diketahui dari skor FTND rokok elektronik yang ditemukan lebih tinggi daripada pengguna rokok konvensional.

Walaupun terdapat berbedaan dari hasil dengan beberapa penelitian sebelumnya, secara umum baik penelitian ini maupun penelitian sebelumnya menemukan hasil konsisten bahwa potensi kecanduan pengguna rokok elektronik sebanding dengan kadar nikotin. Pengguna rokok elektronik yang mengandung nikotin menunjukkan tingkat ketergantungan yang lebih tinggi dibandingkan dengan pengguna rokok elektronik bebas nikotin.

Ditiinjau dari motivasi alasan merokok menunjukkan tidak terdapat perbedaan yang signifikan antara faktor stimulasi, kesenangan, crutch, kebiasaan, faktor stres, dan faktor sosial dengan tingkat ketergantungan nikotin. Namun, pada faktor craving terdapat perbedaan yang signifikan. Mayoritas dari pengguna rokok yang memiliki alasan craving berada pada kategori ketergantungan yang rendah menurut kuesioner FTND.

Motivasi alasan merokok karena craving termasuk ke dalam kategori ketergantungan merokok yaitu perokok merasa gelisah ketika tidak ada rokok didekatnya dan baru akan kembali tenang setelah merokok. Waktu untuk terjadinya ketergantungan merokok dapat memerlukan waktu sekitar beberapa bulan sampai tiga tahun. ${ }^{1} \mathrm{Hal}$ ini menunjukkan bahwa sebagian besar sampel pada penelitian belum mencapai fase ketergantungan merokok sehingga motivasi alasan craving berbeda secara signifikan dibandingkan dengan kategori motivasi alasan merokok yang lainnya.

Penelitian ini memiliki beberapa keterbatasan, yaitu pertama, penggunaan desain cross-sectional tidak dapat merekam data riwayat perilaku merokok yang dilaporkan responden, terutama terkait kadar nikotin dan frekuensi mengkonsumsi rokok per hari. Kedua, tingkat ketergantungan nikotin tidak dikonfirmasi secara biokimia melalui kadar nikotin dalam darah atau cotinine dalam urin atau air liur. Ketiga, kandungan nikotin pada $e$ -liquid rokok elektronik diketahui dari jawaban responden pada kuesioner sehingga data yang didapatkan bervariasi dan menghasilkan standar deviasi yang besar. 
Keempat, penelitian ini terbatas pada sampel kecil (45 responden) pengguna rokok elektronik untuk populasi usia remaja dan dewasa muda. Ukuran sampel yang kecil dapat menyebabkan data tidak terdistribusi normal, sehingga pengujian statistik parametrik tidak dapat dilakukan. Responden penelitian ini merupakan kelompok remaja sampai dewasa muda dengan usia antara 16 30 tahun dan berpendidikan SMA, diploma dan Sarjana. Hasil penelitian ini tidak dapat digeneralisasikan untuk semua kelompok usia dan pendidikan. Pada penelitian ini dilakukan menggunakan kuesioner online sehingga data yang didapatkan cenderung impersonal dan tidak spesifik.

\section{Kesimpulan}

Penelitian menunjukkan perokok elektronik mempunyai tingkat ketergantungan nikotin yang lebih tinggi dibandingkan perokok konvensional. Penggunaan rokok elektronik dapat membawa risiko kecanduan yang lebih tinggi dibandingkan risiko dari rokok tembakau yang dihisap, terutama di antara orang dewasa muda. Skor Fagerström yang lebih tinggi di antara perokok elektronik menunjukkan bahwa orang muda memiliki risiko kecanduan yang sangat tinggi.

Terdapat perbedaan signifikan mengenai tingkat ketergantungan nikotin berdasarkan motivasi alasan merokok pada kategori craving, tetapi tidak terdapat perbedaan yang signifikan mengenai tingkat ketergantungan nikotin berdasarkan motivasi alasan merokok pada kategori stimulasi, kesenangan, crutch, kebiasaan, faktor stres, dan faktor sosial.

\section{Saran}

Perlu dilakukan penelitian dengan jumlah sampel yang lebih banyak dalam mengetahui tingkat ketergantungan nikotin berdasarkan motivasi alasan merokok dan perbandingan tingkat ketergantungan nikotin pada perokok konvensional dan perokok elektronik untuk mendapatkan sampel yang dapat merepresentasikan populasi umum.

Perlu dilakukan pemeriksaan laboratorium atau biomarker tambahan, yaitu pengukuran nikotin dalam darah dan cotinine dalam urin untuk mendapatkan tingkat ketergantungan nikotin yang lebih akurat.

\section{Daftar Pustaka}

1. World Health Organization (WHO). WHO Report 2019 on The Global Tobacco Epidemic 2019. (Online). 2019. http:// www.who.int/.

2. Depkes RI. Hasil Riset Kesehatan Dasar 2018, Jakarta: Riset Kesehatan Dasar, 2018.

3. Brożek GM, Jankowski M, Lawson JA, Shpakou A, Poznański M, Zielonka TM, Klimatckaia L, Loginovich $Y$, Rachel M, Gereová J, Golonko J. The Prevalence of Cigarette and E-Cigarette Smoking among Students in Central and Eastern Europe-Results of the YUPESS Study. International Journal of Environmental Research and Public Health. 2019; 16 (13):2297.

4. Morgenstern M, Nies A, Goecke M, Hanewinkel R. E-Cigarettes and the Use of Conventional Cigarettes: A Cohort Study in $10^{\text {th }}$ Grade Students in Germany. Deutsches Ärzteblatt International. 2018; 115(14):243.

5. Arias-Carrión O, Stamelou M, MurilloRodríguez $E$, Menéndez-González $M$, Pöppel E. Dopaminergic Reward System: a Short Integrative Review. International Archives of Medicine. 2010; 3(1):1-6.6.

6. Benowitz NL. Nicotine Addiction. New England Journal of Medicine. 2010; 362 (24):2295-303.7.

7. CDC. Learn about Nicotine Therapy. Using Nicotine Replacement Therapy. (Online). 2020. https://www.cdc.gov/ tobacco/campaign/tips/quit-smoking/ guide/explore-medications.html. Diakses 29 Mei 2020.

8. WHO (World Health Organization). Gender, Women, and the Tobacco Epidemic. Geneva: WHO. 2010. P. 137148.

9. SIRKESNAS. Survei Indikator Kesehatan Nasional. Jakarta: Badan Penelitian Pengembangan Kesehatan Kementerian Kesehatan RI. 2016. 
10. Badan Pengawas Obat dan Makanan (BPOM). Kajian Rokok Elektronik di Indonesia. Edisi Kedua. Jakarta: Direktorat Pengawasan Narkotika, Psikotropika dan Zat Adiktif. Badan Pengawas Obat dan Makanan. 2017.

11. Jankowski M, Krzystanek M, Zejda JE, Majek P, Lubanski J, Lawson JA, Brozek G. E-cigarettes are More Addictive than Traditional Cigarettes-a Study in Highly Educated Young People. International Journal of Environmental Research and Public Health. 2019; 16(13):2279.16.

12. Goniewicz ML, Hajek $P$, McRobbie H. Nicotine Content of Electronic Cigarettes, Its Release in Vapour and Its Consistency Across Batches: Regulatory Implications. Addiction. 2014; 109(3):500-7.

13. González-Roz A, Secades-Villa R, Weidberg S. Evaluación de los Niveles de Dependencia de La Nicotina en Usuarios de Cigarrillos Electrónicos (Evaluating Nicotine Dependence Levels in ECigarette Users). Adicciones. 2017; 29 (2):136-8.
14. Etter JF, Eissenberg T. Dependence Levels in Users of Electronic Cigarettes, Nicotine Gums and Tobacco Cigarettes. Drug and Alcohol Dependence. 2015; 147:68-75.

15. Liu G, Wasserman E, Kong L, Foulds J. A Comparison of Nicotine Dependence among Exclusive E-cigarette and Cigarette Users in the PATH Study. Preventive Medicine. 2017; 104:86-91.

16. Hajek P, Przulj D, Phillips A, Anderson R, McRobbie $H$. Nicotine Delivery to Users from Cigarettes and from Different Types of E-Cigarettes. Psychopharmacology. 2017; 234(5):773-9.

17. Jankowski M, Brozek G, Lawson J, Skoczynski S, Zejda JE. E-smoking: Emerging Public Health Problem?. International Journal of Occupational Medicine and Environmental Health. $2017 ; 30(3): 329$.

18. Owotomo O, Maslowsky J, Loukas A, Perceptions of the Harm and Addictiveness of Conventional Cigarette Smoking among Adolescent E-Cigarette Users. J Adolesc Health. 2018; 62:87-93. 